\title{
Erratum to: Cost-effectiveness of clostridial collagenase ointment on wound closure in patients with diabetic foot ulcers: economic analysis of results from a multicenter, randomized, open-label trial
}

\author{
Travis A. Motley ${ }^{1}$, Adrienne M. Gilligan ${ }^{2,3^{*}}$, Darrell L. Lange ${ }^{2,4}$, Curtis R. Waycaster ${ }^{2,3}$ and Jaime E. Dickerson Jr $r^{2,5}$
}

\section{Erratum}

Following publication of the original article [1] it was brought to our attention that some of the data within the article required correction.

Hence, please note that in the second paragraph of the section headed 'Three-state markov model and transition probabilities' there is a sentence which reads as:

"At the end of 12 weeks, approximately $65 \%$ of patients in the $\mathrm{CCO}+\mathrm{SSD}$ group were considered healed compared to $47 \%$ in the Control group."

However, this should read as:

"At the end of 12 weeks, approximately $47 \%$ of patients in the $\mathrm{CCO}+\mathrm{SSD}$ group were considered healed compared to $\mathbf{3 2} \%$ in the Control group."

This alteration does not affect the methodology or results.

\begin{abstract}
Author details
${ }^{1}$ University of North Texas Health Sciences Center, Bone and Joint Institute, Fort Worth, TX, USA. ${ }^{2}$ Smith \& Nephew Inc., 3909 Hulen Street, Fort Worth, TX 76107, USA. ${ }^{3}$ Department of Pharmacotherapy, University of North Texas Health Sciences Center, Fort Worth, TX, USA. ${ }^{4}$ Department of Cell Biology and Anatomy, University of North Texas Health Sciences Center, Fort Worth, TX, USA. ${ }^{5}$ Department of Pediatrics, University of North Texas Health Sciences Center, Fort Worth, TX, USA.
\end{abstract}

Received: 27 July 2016 Accepted: 27 July 2016

Published online: 04 August 2016

\section{References}

1. Motley, et al. Cost-effectiveness of clostridial collagenase ointment on wound closure in patients with diabetic foot ulcers: economic analysis of results from a multicenter, randomized, open-label trial. Journal of Foot and Ankle Research. 2015;8:7.

\footnotetext{
* Correspondence: Adrienne.Gilligan@smith-nephew.com

${ }^{2}$ Smith \& Nephew Inc., 3909 Hulen Street, Fort Worth, TX 76107, USA

${ }^{3}$ Department of Pharmacotherapy, University of North Texas Health Sciences Center, Fort Worth, TX, USA
}

Full list of author information is available at the end of the article

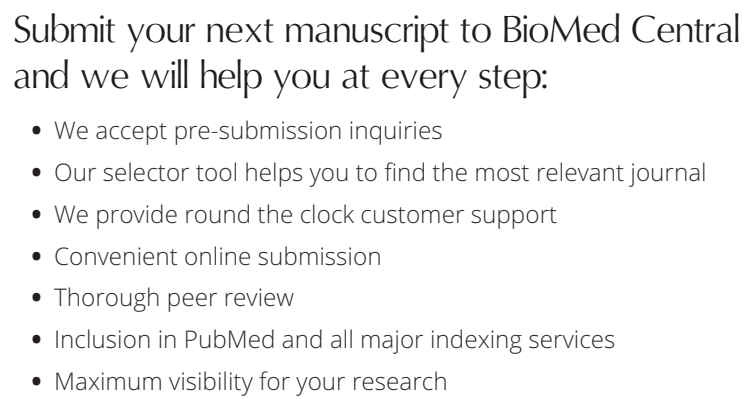

- We accept pre-submission inquiries

- Our selector tool helps you to find the most relevant journal

- We provide round the clock customer support

- Convenient online submission

- Thorough peer review

- Inclusion in PubMed and all major indexing services

- Maximum visibility for your research

Submit your manuscript at www.biomedcentral.com/submit (c) 2016 The Author(s). Open Access This article is distributed under the terms of the Creative Commons Attribution 4.0 International License (http://creativecommons.org/licenses/by/4.0/), which permits unrestricted use, distribution, and reproduction in any medium, provided you give appropriate credit to the original author(s) and the source, provide a link to the Creative Commons license, and indicate if changes were made. The Creative Commons Public Domain Dedication waiver (http://creativecommons.org/publicdomain/zero/1.0/) applies to the data made available in this article, unless otherwise stated. 